\title{
UPAYA PENINGKATAN PENDAPATAN MELALUI USAHA PENGAWETAN IKAN ASIN MUJAIR DI KABUPATEN LAMONGAN
}

\section{INCOME INCREASE EFFORTS THROUGH THE BUSINESS OF PRESERVING THE SALT FISH OF TILAPIA IN LAMONGAN DISTRICT}

\author{
Wachidatus Sa'adah \\ Fakultas Perikanan Universitas Islam Lamongan \\ Email: wachidaafandi@gmail.com \\ (Diterima 19-12-2021; Disetujui 22-01-2022)
}

\begin{abstract}
ABSTRAK
Kabupaten Lamongan merupakan wilayah memiliki potensi produksi hasil perikanan. Jika saat ketersediaan ikan melimpah di pasar maka tidak akan habis terjual, dan itu akan menimbulkan kerugian. Ikan merupakan bahan pangan yang mudah rusak (membusuk). Oleh karena itu, agar ikan dapat dimanfaatkan semaksimal mungkin, maka perlu dijaga kondisinya. Pengawetan dengan penggaraman merupakan salah satu cara untuk mempertahankan ikan dari proses pembusukan. Adapun komoditi yang digunakan adalah ikan mujair, dipilihnya ikan mujair karena ikan ini diminati oleh konsumen disamping tidak banyak durinya juga rasanya lebih enak dari ikan lainnya. Tujuan dari penelitian ini adalah untuk mengetahui tingkat pendapatan dari usaha pengawetan ikan asin mujair di Kelurahan Tumenggungan Kabupaten Lamongan. Metode penelitian yang dilakukan adalah penelitian dengan pendekatan kuantitatif. Hasil penelitian bahwa pendapatan per tahun usaha pengawetan ikan asin mujair di Kelurahan Tumenggungan Kabupaten Lamongan adalah $\mathrm{Rp} 478.170 .000$, dengan $\mathrm{R} / \mathrm{C}$ ratio 1,16 .
\end{abstract}

Kata kunci: ikan mujair, pengawetan, ikan asin, pendapatan

\section{ABSTRACT}

Lamongan Regency is an area that has the potential to produce fishery products. If the availability of fish is abundant in the market, it will not be sold out, and it will cause losses. Fish is a food that is easily damaged (rotten). Therefore, so that fish can be utilized as much as possible, it is necessary to maintain their condition. Preservation by salting is one way to defend fish from the decay process. The commodity used is tilapia fish, the choice of tilapia because this fish is in demand by consumers, besides not having many spines, it also tastes better than other fish. The purpose of this study was to determine the level of income from the preservation of salted tilapia fish in Tumenggungan Village, Lamongan Regency. The research method used is research with a quantitative approach. The results showed that the annual income of the salted tilapia fish preservation business in Tumenggungan Village, Lamongan Regency was Rp. 478.170.000, and the $R / C$ ratio was 1.16 .

Keyword: tilapia fish, preservation, salted fish, income

\section{PENDAHULUAN}

Sejak beberapa abad yang lalu manusia telah memanfaatkan ikan sebagai salah satu bahan pangan yang banyak mengandung protein. Protein ikan sangat diperlukan oleh manusia karena selain lebih mudah dicerna juga mengandung asam amino dengan pola 


\section{UPAYA PENINGKATAN PENDAPATAN MELALUI USAHA PENGAWETAN \\ IKAN ASIN MUJAIR DI KABUPATEN LAMONGAN \\ Wachidatus Sa'adah}

yang hampir sama dengan asam amino yang terdapat di dalam tubuh manusia.

Kebutuhan setiap manusia akan protein hewani sangat bervariasi, tergantung pada usia, jenis kelamin, dan aktivitas yang dilakukan. Bagi tubuh manusia, daging ikan mempunyai beberapa fungsi, yaitu: 1) menjadi sumber energi yang sangat dibutuhkan dalam menunjang aktivitas kehidupan sehari-hari; 2) membantu pertumbuhan dan pemeliharaan tubuh; 3) mempertinggi daya tahan tubuh terhadap serangan penyakit dan juga memperlancar proses-proses fisiologis di dalam tubuh (Eddy, dkk, 2016).

Namun telah kita ketahui bahwa ikan merupakan bahan pangan yang mudah rusak (membusuk). Proses pembusukan pada ikan dapat disebabkan terutama oleh aktivitas enzim yang terdapat di dalam tubuh ikan sendiri, dan aktivitas mikroorganisme. Kelemahankelemahan yang dimiliki oleh ikan telah dirasakan sangat menghambat usaha pemasaran hasil perikanan dan tidak jarang menimbulkan kerugian besar, terutama saat produksi ikan melimpah. Oleh karena itu, agar ikan dan hasil perikanan lainnya dapat dimanfaatkan semaksimal mungkin, maka perlu dijaga kondisinya. Pengawetan merupakan salah satu cara untuk mempertahankan ikan dari proses pembusukan, sehingga mampu disimpan lama sampai tiba waktunya untuk dijadikan sebagai bahan konsumsi. Usaha dalam melakukan pengawetan dapat dilakukan dengan berbagai macam cara, misalnya, penggaraman, pemindangan, pengeringan, dan pengasapan (Rabiatul, 2014).

Adapun pengawetan yang dapat diterapkan agar proses pembusukan tidak terjadi salah satunya adalah dengan penggaraman. Adapun tujuan utama dari penggaraman adalah agar menjadi awet karena garam dapat menghambat atau membunuh bakteri penyebab pembusukan pada ikan. Garam merupakan faktor utama dalam proses penggaraman ikan. Sebagai bahan pengawet, kemurnian garam sangat mempengaruhi mutu ikan yang dihasilkan. Garam juga merupakan bahan pembantu yang sengaja ditambahkan atau diberikan dengan tujuan untuk meningkatkan konsistensi, nilai gizi, cita rasa, mengendalikan keasamaan dan kebasaan, serta dapat memantapkan bentuk dan rupa.

Hasil akhir dari penggaraman adalah ikan asin, yaitu ikan yang telah mengalamai proses penggaraman dan 
pengeringan. Cara ini telah banyak dilakukan di berbagai negara termasuk Indonesia. Ikan asin merupakan salah satu produk perikanan yang mempunyai kedudukan penting, hampir 65\% produk perikanan masih diolah dan diawetkan dengan cara penggaraman. Sehingga tidak mengherankan apabila ikan asin termasuk dalam sembilan bahan pokok penting bagi kebutuhan masyarakat.

Kabupaten Lamongan merupakan wilayah yang memiliki potensi produksi hasil perikanan, baik darat maupun tangkap. Jika pada saat ketersediaan ikan melimpah di pasar maka tidak akan habis terjual, dan itu akan menimbulkan kerugian. Oleh karena itu, perlu dilakukan proses pengawetan yakni berupa penggaraman. Adapun komoditi yang digunakan untuk proses penggaraman adalah ikan mujair, dipilihnya ikan mujair karena ikan ini diminati oleh konsumen disamping tidak banyak durinya juga rasanya lebih enak dari ikan lainnya.

Dari latar belakang tersebut, maka tujuan penelitian ini adalah untuk mengetahui tingkat pendapatan dari usaha pengawetan ikan asin mujair di Kelurahan Tumenggungan Kabupaten Lamongan.

\section{METODE PENELITIAN}

Penelitian ini dilaksanakan di Kelurahan Tumenggungan Kabupaten Lamongan. Jenis penelitian yang dilakukan adalah penelitian dengan pendekatan kuantitatif, yaitu penelitian yang menggunakan angka (numerical) dari hasil observasi dengan maksud untuk menjelaskan fenomena dari observasi (Aziz, 2012).

Teknik penarikan sampel yang ditetapkan dalam penelitian ini berdasarkan metode purposive sample, yaitu teknik penentuan sampel dengan pertimbangan khusus sehingga layak dijadikan sampel (Juliansyah, 2011). Pertimbangan khusus tersebut karena alasan keterbatasan waktu, tenaga, dan dana, sehingga tidak dapat mengambil sampel yang besar dan jauh (Suharsimi, 2010). Pengambilan sampel harus didasarkan atas ciri-ciri, sifat-sifat atau karakteristik tertentu, yang merupakan ciri-ciri pokok populasi. Atas dasar itu maka sampel yang dipilih adalah sentra usaha pengawetan ikan asin mujair di Kelurahan Tumenggungan Kabupaten Lamongan.

Teknik pengumpulan data dalam penelitian ini menurut Aziz (2012) ada dua sumber data, yaitu data primer dan data sekunder. Data primer adalah data 


\section{UPAYA PENINGKATAN PENDAPATAN MELALUI USAHA PENGAWETAN \\ IKAN ASIN MUJAIR DI KABUPATEN LAMONGAN \\ Wachidatus Sa'adah}

yang diperoleh sendiri oleh perorangan/organisasi langsung melalui objeknya. Data sekunder adalah data yanag diperoleh dalam bentuk yang sudah jadi berupa publikasi. Menurut Juliansyah (2011), data primer umumnya berupa karakteristik demografi atau sosioekonomi, sikap atau pendapat, kesadaran atau pengetahuan, minat, motivasi, prilaku (tindakan atau penggunaan). Sedangkan data sekunder terdiri atas data internal suatu organisasi dan data eksternal yang dipublikasikan.

Rancangan analisis data adalah berbagai analisa data penelitian agar rumusan masalah penelitian dapat terpecahkan, serta tujuan penelitian dapat tercapai. Rancangan penelitian sudah ditetapkan dari awal sejak menentukan ide penelitian. atau sejak peneliti menemukan masalah penelitian. Adapun analisis data yang digunakan dalam penelitian ini adalah analisis pendapatan usaha. Untuk menganalisis pendapatan usaha harus terlebih dahulu mengetahui biaya total (TC) dan penerimaan total (TR).

Biaya diklasifikasikan menjadi dua, yaitu biaya tetap dan biaya tidak tetap atau biaya variabel. Menurut Rita (2017), biaya tetap adalah semua jenis biaya yang besar-kecilnya yang tidak tergantung pada besar-kecilnya produksi. Yang termasuk dalam biaya tetap adalah sewa lahan dan pajak. Jumlah biaya tetap adalah konstan. Sedangkan biaya tidak tetap adalah biaya yang besar-kecilnya berhubungan langsung dengan jumlah produksi. Contohnya adalah biaya untuk sarana produksi. Sifat biaya ini berubahubah. Untuk mengetahui keseluruhan total biaya yang dikeluarkan di dalam produksi yaitu dengan cara menghitung biaya total yang diperoleh dari jumlah biaya tetap dan biaya tidak tetap, Menurut Soekartawi (2006) rumus biaya total adalah sebagai berikut:

$$
\mathrm{TC}=\mathrm{FC}+\mathrm{VC}
$$

Keterangan:

TC = biaya total (Total Cost)

$\mathrm{FC}=$ biaya tetap (Fixed Cost)

$\mathrm{VC}=$ biaya tidak tetap (Variable Cost)

Penerimaan adalah perkalian antara produksi yang diperoleh dengan harga jual. Rumus penerimaan adalah sebagai berikut:

$$
\mathrm{TR}=\mathrm{Y} . \mathrm{Py}
$$

Keterangan:

$\mathrm{TR}=$ penerimaan total $($ Total Revenue $)$

$\mathrm{Y}=$ output

Py $=$ harga output

Pendapatan adalah selisih antara penerimaan total dan biaya total. Rumus pendapatan adalah sebagai berikut: 


$$
\pi=\mathrm{TR}-\mathrm{TC}
$$

Keterangan:

$\pi=$ pendapatan

$\mathrm{TR}=$ penerimaan total

$\mathrm{TC}=$ biaya total

Untuk mengetahui apakah dari pendapatan usaha yang diterima tersebut dikatakan untung dan layak tidak harus dinyatakan dengan dalam rupiah atau uang namun dapat diuji dengan $\mathrm{R} / \mathrm{C}$ ratio (Rita, 2017). Menurut Soekartawi (2006), $\mathrm{R} / \mathrm{C}$ ratio (Return Cost ratio) adalah perbandingan antara penerimaan total dan biaya total. Rumus $\mathrm{R} / \mathrm{C}$ ratio adalah sebagai berikut:

$$
\begin{array}{ll}
\mathrm{R} / \mathrm{C} \text { Ratio } & =\mathrm{a} \\
\mathrm{R} & =\mathrm{Py} . \mathrm{Y} \\
\mathrm{C} & =\mathrm{FC}+\mathrm{VC} \\
\mathrm{a} & =\{(\mathrm{Py} \cdot \mathrm{Y}) /(\mathrm{FC}+\mathrm{VC})\}
\end{array}
$$

Keterangan:

$$
\begin{aligned}
& \mathrm{R}=\text { penerimaan total } \\
& \mathrm{C}=\text { biaya total } \\
& \mathrm{Py}=\text { harga output } \\
& \mathrm{Y}=\text { output } \\
& \mathrm{FC}=\text { biaya tetap } \\
& \mathrm{VC}=\text { biaya tidak tetap }
\end{aligned}
$$

Kriteria:

$\mathrm{R} / \mathrm{C}>1$, dikatakan menguntungkan

$\mathrm{R} / \mathrm{C}=1$, dikatakan tidak untung dan tidak rugi

$\mathrm{R} / \mathrm{C}<1$, dikatakan rugi

\section{HASIL DAN PEMBAHASAN}

\section{A. Keadaan Umum Daerah}

Tumenggungan adalah sebuah kelurahan yang berada di wilayah Kecamatan Lamongan Kabupaten Lamongan. Luas wilayahnya adalah 1,45 $\mathrm{km}^{2}$. Wilayah Kelurahan Tumenggungan terletak di dataran rendah dan ketinggiannya $4 \mathrm{~m}$ dari permukaan laut dengan curah hujan $2.000 \mathrm{~mm} /$ tahun serta suhu rata-rata $34^{\circ} \mathrm{C}$. Jumlah penduduknya 4.428 jiwa yang terdiri dari 2.167 lakilaki dan 2.261 perempuan. Penduduk Tumenggungan bermata pencaharian sebagai petani, pembudidaya dan pengusaha di bidang industri rumah tangga.

Batas-batas wilayah Kelurahan Tumenggungan adalah sebagai berikut:

- Sebelah Utara berbatasan dengan Kelurahan Sukorejo dan

Kelurahan Sidokumpul

- Sebelah Timur berbatasan dengan Kelurahan Sidokumpul dan Kelurahan Jetis

- Sebelah Selatan berbatasan dengan Kelurahan Sidoharjo dan Kelurahan Jetis

- Sebelah Barat berbatasan dengan Kelurahan Sukomulyo dan Kelurahan Sukorejo 


\section{UPAYA PENINGKATAN PENDAPATAN MELALUI USAHA PENGAWETAN \\ IKAN ASIN MUJAIR DI KABUPATEN LAMONGAN \\ Wachidatus Sa'adah}

\section{B. Gambaran Usaha}

Usaha pengawetan ikan asin mujair ini berlokasi di Kelurahan Tumenggungan Kecamatan Lamongan Kabupaten Lamongan. Tepatnya berada di dalam area sisi sebelah barat pasar ikan Lamongan. Usaha ini sudah ada sejak tahun 2001, dengan bangunan dibuat semi permanen berukuran $3 \mathrm{~m} \times 3 \mathrm{~m}$, dan status kepemilikan bangunannya adalah sewa. Jumlah pelaku usahanya sampai saat ini ada 18 orang.

Melihat lokasinya yang sangat strategis yaitu dekat dengan pasar ikan, membuat pelaku usaha sangat mudah untuk menjangkau perolehan bahan bakunya. Perolehan bahan baku ikan mujair tidak sepenuhnya sama, karena ketersediaannya dipengaruhi oleh musim. Jika saat musim maka ikan berlimpah dan sebaliknya jika tidak musim maka sangat jarang dijumpai, sehingga ini akan mempengaruhi volume produksi.

Kegiatan usaha ini sebagian besar dilakukan oleh laki-laki yang pekerjaan utamanya adalah petani dan pembudidaya. Mereka menganggap bahwa dengan hasil tambahan dari pendapatan usaha lain, maka kebutuhan yang diinginkan bisa terpenuhi, karena pendapatan bertambah. Oleh karena itu, mereka mengupayakan ada pekerjaan tambahan lain dan mereka memutuskan untuk melakukan kegiatan usaha pengawetan ikan asin mujair ini.

Area pemasaran dari ikan asin mujair tidak hanya di wilayah Lamongan saja, namun juga sampai ke wilayah lain yaitu Jombang dan Mojokerto.

\section{Penggaraman Ikan}

Penggaraman merupakan proses pengawetan yang banyak dilakukan di berbagai negara, termasuk Indonesia. Adapun tujuan utama dari penggaraman adalah untuk memperpanjang daya tahan dan daya simpan. Media pengawet yang digunakan untuk penggaraman adalah garam, bisa berbentuk kristal maupun larutan. Ikan yang mengalami proses penggaraman akan menjadi awet karena garam dapat menghambat atau membunuh bakteri penyebab kebusukan ikan. Proses pengawetan dengan penggaraman ini dilakukan dengan cara mengurangi kadar air dalam badan ikan sampai titik tertentu sehingga bakteri tidak dapat hidup dan berkembang biak lagi (Latif, 2014).

Pengawetan ikan dengan penggaraman terdiri atas dua proses, yaitu proses penggaraman dan proses pengeringan. Hasil akhir dari pengawetan dengan proses penggaraman adalah ikan asin. Dalam skala nasional ikan asin 
masuk dalam bahan pokok yang dibutuhkan bagi masyarakat mulai kalangan bawah sampai atas.

Adapun pelaksanaan proses penggaraman ikan adalah sebagai berikut:

1. Persiapan

- Menyediakan bahan baku berupa ikan mujair berdasarkan ukuran, dan tingkat kesegaran, hal ini mempunyai tujuan agar meyeragamkan proses penetrasi pada saat penggaraman berlangsung;

- Menyediakan peralatan berupa pisau untuk membersihkan dan menyiangi ikan, bak cuci yang berfungsi untuk mencuci ikan setelah dibersihkan dan disiangi, bak air yang berfungsi untuk menyimpan air bersih untuk mencuci ikan, bak rendam yang berfungsi untuk merendam ikan dengan garam setelah dicuci, para-para yang berfungsi untuk menjemur ikan agar ikan cepat kering, dan keranjang bambu yang berfungsi untuk mengangkut ikan segar dan ikan asin yang siap untuk dipasarkan.

2. Penanganan Ikan

Tempatkan ikan mujair ke dalam wadah berdasarkan ukuran dan tingkat kesegarannya. Kemudian ikan yang akan diolah dicuci dari kotoran yang melekat pada tubuh bagian luar (sisik, dan siripnya), lalu dilakukan penyiangan dengan membuang insang dan isi perutnya, penyiangan ikan bertujuan untuk menghilangkan sebagian besar bakteri pembusuk yang terdapat pada tubuh ikan. Setelah itu ikan dicuci dengan air bersih sampai tubuh ikan benar-benar bersih dan tiriskan dengan posisi bagian perut menghadap ke bawah agar tidak ada air yang menggenang terutama pada rongga perut.

\section{Penggaraman}

Proses penggaraman yang dilakukan pada penelitian ini adalah penggaraman basah (wet salting), adapun prosesnya sebagai berikut:

- Selesai ditiriskan, ikan dapat langsung digarami sesuai ukurannya dengan cara melumuri ikan dengan garam dan rongga perut diisi dengan garam.

- Susunlah ikan secara berlapis-lapis di dalam bak perendaman garam kurang lebih selama 1 hari, jika dirasa cukup waktunya, maka proses penggaraman ikan dapat dianggap selesai, dan ikan diangkat dari bak kemudian dicuci sampai bersih setelah itu ditiriskan. 


\section{UPAYA PENINGKATAN PENDAPATAN MELALUI USAHA PENGAWETAN \\ IKAN ASIN MUJAIR DI KABUPATEN LAMONGAN \\ Wachidatus Sa'adah}

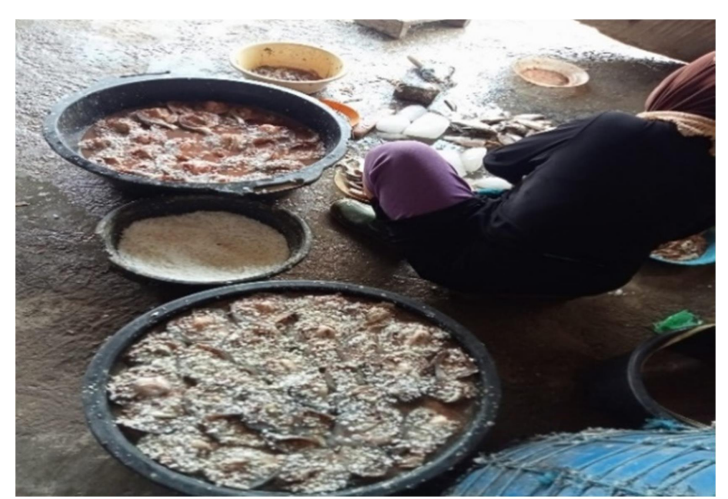

Gambar 1. Penggaraman Ikan

\section{Pengeringan}

Jemurlah ikan di para-para atau tempat pengeringan, sesekali jemuran ikan dibalik-balik supaya cepat kering. Apabila panas cukup, maka penjemuran memerlukan waktu kurang lebih 2 hari atau lebih.

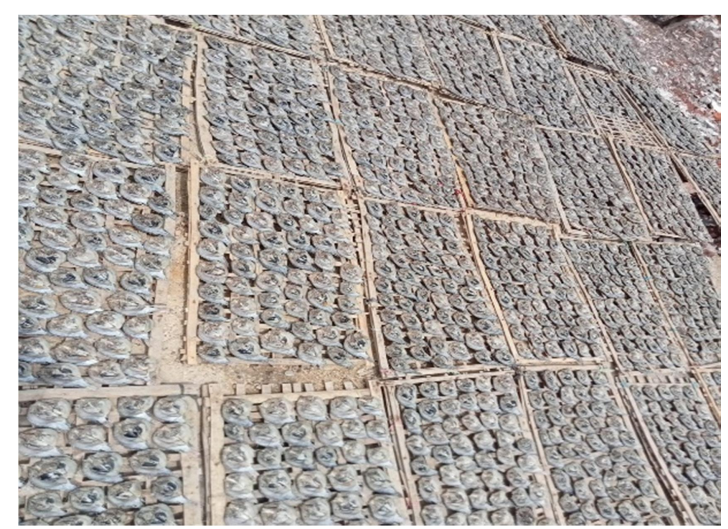

Gambar 2. Pengeringan Ikan

\section{Penyimpanan}

Setelah kering, ikan-ikan tersebut kemudian disusun secara teratur di wadah keranjang bambu, dan berikutnya letakkan keranjang bambu di dalam ruangan yang kering dengan ventilasi yang baik. Daya awet ikan asin dapat mencapai 6 bulan.

\section{Pendapatan Usaha}

Penelitian tentang tema di atas telah banyak dilakukan pada penelitianpenelitian sebelumnya diantaranya oleh Sulistyowati et al., 2021; Desi, D, et al., 2020; Wachidatus, S, dalam Ekonomi et al., 2017.

Setiap kegiatan usaha, hasil akhirnya adalah memperoleh keuntungan, karena keuntungan berpengaruh terhadap peningkatan pendapatan, sehingga dapat memenuhi semua kebutuhan yang diperlukan.

Bagaimana usaha ini bisa berjalan dengan baik dan tidak terkendala tentunya tidak terlepas dari modal, yang dimaksud dengan modal disini adalah biaya. Adapun biaya yang dikeluarkan ada dua yaitu biaya tetap dan biaya tidak tetap. Untuk mengetahui berapa pengeluaran dari masing-masing biaya tersebut ditunjukkan pada Tabel 1, 2, dan 3.

Tabel 1. Biaya Tetap Usaha Pengawetan Ikan Asin Mujair Per Tahun

\begin{tabular}{lc}
\hline No Uraian Biaya & Jumlah $(\mathrm{Rp})$ \\
\hline 1. Sewa bangunan & 32.400 .000 \\
2. Retribusi & 10.800 .000 \\
3. Penyusutan alat & 6.030 .000 \\
\hline Jumlah & 49.230 .000 \\
\hline Sumber: Data Primer Terolah (2021) &
\end{tabular}


Tabel 2. Biaya Tidak Tetap Usaha Pengawetan Ikan Asin Mujair Per Tahun

\begin{tabular}{lr}
\hline No Uraian Biaya & Jumlah (Rp) \\
\hline 1. Ikan mujair segar & 2.047 .500 .000 \\
2. Garam & 282.600 .000 \\
3. Upah tenaga kerja & 540.000 .000 \\
\hline Jumlah & 2.870 .100 .000 \\
\hline
\end{tabular}

Sumber: Data Primer Terolah (2021)

Tabel 3. Biaya Total Usaha Pengawetan Ikan Asin Mujair Per Tahun

\begin{tabular}{lr}
\hline No Jenis Biaya & Jumlah (Rp) \\
\hline 1. Biaya tetap & 49.230 .000 \\
2. Biaya tidak tetap & 2.870 .100 .000 \\
\hline Jumlah & 2.919 .330 .000 \\
\hline \multicolumn{2}{l}{ Sumber: Data Primer Terolah (2021) }
\end{tabular}

Tabel 1, 2, dan 3 menunjukkan bahwa pengeluaran per tahun untuk biaya tetapnya adalah Rp49.230.000, kemudian biaya tidak tetapnya adalah Rp2.870.100.000, dan total keseluruhan biayanya adalah Rp2.919.330.000.

Setelah mengetahui berapa biaya yang dikeluarkan selanjutnya adalah berapa penerimaan yang diperoleh. Penerimaan ini berasal dari hasil keseluruhan produksi dikalikan dengan harga jualnya. Untuk mengetahui berapa penerimaan yang diperoleh ditunjukkan pada Tabel 4.

Tabel 4. Penerimaan Usaha Pengawetan Ikan Asin Mujair Per Tahun

\begin{tabular}{lcc}
\hline Produksi $(\mathrm{Kg})$ & Harga $(\mathrm{Rp})$ & \multicolumn{1}{c}{ Jumlah $(\mathrm{Rp})$} \\
\hline 337.500 & 5.000 & 1.687 .500 .000 \\
180.000 & 7.000 & 1.260 .000 .000 \\
45.000 & 10.000 & 450.000 .000 \\
\hline Jumlah & \multicolumn{3}{c}{3.397 .500 .000} \\
\hline \multicolumn{2}{l}{ Sumber: Data Primer Terolah $(2021)$}
\end{tabular}

Tabel 4 menunjukkan bahwa penerimaan per tahun yang diperoleh oleh usaha ini adalah Rp3.397.500.000.

Dalam kegiatan usaha tidak cukup dengan hasil penerimaan saja, namun harus dihitung berapa keuntungan/ pendapatan yang diperoleh. Pendapatan diperoleh dari selisih antara penerimaan dengan biaya total. Untuk mengetahui berapa pendapatan yang diperoleh ditunjukkan pada Tabel 5.

Tabel 5. Pendapatan Usaha Pengawetan Ikan Asin Mujair Per Tahun

Penerimaan (Rp) Biaya Total (Rp) Jumlah (Rp)

$\begin{array}{lll}3.397 .500 .000 & 2.919 .330 .000 & 478.170 .000\end{array}$

Sumber: Data Primer Terolah (2021)

Tabel 5 menunjukkan bahwa pendapatan per tahun yang diperoleh oleh usaha ini adalah Rp478.170.000.

Sebagai parameter dari keuntungan/pendapatan tidak harus dinyatakan dalam bentuk uang, namun dapat dinyatakan dengan $\mathrm{R} / \mathrm{C}$ ratio. Adapun $\mathrm{R} / \mathrm{C}$ ratio diperoleh dari rasio antara penerimaan dengan biaya total. Untuk mengetahui berapa $\mathrm{R} / \mathrm{C}$ ratio nya ditunjukkan pada Tabel 6.

Tabel 6. R/C Ratio Usaha Pengawetan Ikan Asin Mujair Per Tahun

\begin{tabular}{lrr}
\hline Penerimaan (Rp) & Biaya Total (Rp) & Jumlah \\
\hline 3.397 .500 .000 & 2.919 .330 .000 & 1,16
\end{tabular}

Sumber: Data Primer Terolah (2021)

Tabel 6 menunjukkan bahwa R/C Rationya adalah 1,16 , ini berarti bahwa usaha ini layak untuk diusahakan. 


\section{KESIMPULAN DAN SARAN}

Berdasarkan hasil penelitian yang telah dilakukan bahwa pendapatan per tahun pelaku usaha pengawetan ikan asin mujair di Kelurahan Tumenggungan Kabupaten Lamongan adalah Rp478.170.000. Dari pendapatan tersebut dikatakan untung dan layak karena $\mathrm{R} / \mathrm{C}$ rationya adalah 1,16

\section{DAFTAR PUSTAKA}

Adawyah, R. (2014). Pengolahan dan Pengawetan Ikan. PT. Bumi Aksara, Jakarta.

Arikunto, S. (2010). Prosedur Penelitian Suatu Pendekatan Praktik. Rineka Cipta, Jakarta.

Darmilayanti, D, et al. (2020). Pendapatan Usaha Pengolahan Ikan Pada KUB Bina Sejahtera di Kelurahan Kangkung Kecamatan Bumi Waras Kota Bandar Lampung. JIIA, 8(3), pp. 490-495.
Eddy, A., \& Evi, L. (2016). Pengawetan Dan Pengolahan Ikan. Kanisius, Yogyakarta.

Sa'adah, W, dalam Ekonomi, P. et al. (2017). Seminar Nasional Seminar Nasional.

Firdaus, M.A. (2012). Metode Penelitian. Jelajah Nusa, Tangerang.

Hanafie, R. (2017). Pengantar Ekonomi Pertanian. CV. Andi Offset, Yogyakarta.

Noor, J. (2011). Metodologi penelitian Skripsi, Tesis, Disertasi dan Karya Ilmiah. Kharisma Putra Utama, Jakarta.

Primyastanto, M. 2011. Feasibility Study Usaha Perikanan (Sebagai Aplikasi Dari Teori Studi Kelayakan Usaha Perikanan. UB Press, Malang.

Sahubawa, L. 2014. Teknologi Pengawetan dan Pengolahan Hasil Perikanan. Gadjah Mada University Press, Yogyakarta.

Soekartawi, 2006. Analisis Usahatani. UI Press, Jakarta.

Sulistyowati, et al. (2021) Upaya Peningkatan Pendapatan Keluarga Melalui Usaha "Bandeng Presto", Patria, 3(1), p. 23. doi: 10.24167/patria.v3i1.2560. 